\title{
Sydney freelance journalists and the notion of professionalism
}

\section{ABSTRACI}

Freelance journalists experience constraints in their practice which impact upon their independence; yet they invoke the idea of professionalism similar to that of the employed journalists to justify their position as journalists. However, the reality of their practice makes them accept the imperative of the rules of game set by news managers and others, which significantly compromises their independence. An in-depth interview of freelance journalists working in print media in Sydney, Australia, reveal that this is a true analysis of the prevailing situation for the freelance journalists, making their claim of professionalism weak. However, the complexity of the situation is manifested in a strong sense of public service prevalent among Sydney freelancers. As freelance journalists are becoming significant in number in many parts of the world (IFJ, 1999), the question of professionalism in freelance journalism should be considered as an important aspect in any comprehensive discussion on journalism.

\section{JAHNNABI DAS}

University of Technology, Sydney

\section{Introduction}

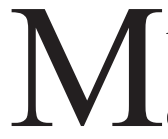

ANY scholars (Soloski, 1989; Hallin, 1996; Henningham, 1990; Meadows, 2001; Dunn, 2003) have discussed issues and questions relevant to journalism and profession, but none has so far incorporated freelance journalism in any such discussion and dealt with issues associated with freelance journalists and professional ideals in journalism. In order to contribute to the gap in literature, this article presents an analysis of the notion of professionalism among freelance journalists in Sydney's print media and relates this perspective to the discussions on journalism and 
professionalism found in Soloski (1989), Friedson (1994) and Hallin (1996). It has been done through an investigation of how the Sydney-based freelance journalists perceived the notion of journalistic professionalism and how these perceptions relate to their actual journalism work experiences.

My recent research on freelance journalists' conditions of work has revealed that Sydney's print media freelance journalists are dissatisfied about adverse conditions in work which impact upon their independence as journalists (Das, 2005). Yet, participants in this study continued their support for the idea of being a professional. Such tension between professional ideals in journalism and increased commercial imperatives of the news organisations is not unique to freelance journalism, but also prominently evident in case of employed journalists, which Hallin (1996) has elaborated in his work. Soloski's (1989) discussion also focuses on how organisational rules in news media impact upon the journalists' professional ideologies. Hallin and Soloski have spotlighted mainly on employees in mainstream news organisations, but the perspectives of employed journalists are also useful in interpreting the experiences of freelance journalists.

\section{Literature review}

In the broader field of communication studies, there is a lack of attention to freelance journalism and little scholarly work is available on this topic (Das, 2005 , p. 18). Of the scant literature, prominent is the surveys and investigations on work conditions of freelance journalists from across the world. These researches reveal freelancers' uninspiring work conditions, financial vulnerability and difficulties in ensuring various rights (IFJ, 1999; Meehan, 2001; Baines, 1999 \& 2002). Besides, some investigations from workplace and labour market perspective advance the argument that restructuring in workplaces, which encourages more casual and fragmented work, has been occurring due to contemporary economic restructuring (Baumann, 2002; Platman, 2003; Gottschall, 2002). Others have highlighted structural issues such as commercial imperatives and technological advances which influence journalism broadly and have important implications for freelance practice in media work (Tunstall, 1996; Franklin, 1997; Forde, 2003; Dombkins, 2003). Another pioneering study of Henningham on journalists' professional issues finds 72 percent of Australian television journalists think that 'journalism should be considered a profession rather than a craft' (Henningham, 1988, quoted in Henningham, 1990, p. 129). Henningham bases his analysis on five 
professional criteria, such as service to the public, knowledge, autonomy, professional organisation and ethical codes, and considers that journalists offer services to their clients on the basis of 'specialised form of knowledge' they possess. However, the obtaining process of such knowledge can not be controlled by a particular type of academic institution (1990, p. 153). Despite this deficiency, Henningham contends that although journalism as an occupation is in an 'ambiguous position', it needs to be considered as a profession as professional forms of behaviour do exist to a strong extent among journalists in many countries (1990, p. 153). Meadows (2001) furthers the position arguing that the idea of professionalism in journalism is a "vague and contradictory one' because the conventional model of professionalism, which is applicable to law or medicine, does not fit into journalism. These conceptual positions are important, but as stated before, none of these studies takes into account the issue of professionalism in freelance journalism or incorporates data obtained from such news workers.

Soloski (1989) examines the relationship between journalists and their organisations to comprehend the way in which the notion of professionalism affects journalists. His work is based on a 'participant-observation' style newsroom study of organisational pressures on journalists' notion of professionalism in the United States. On the basis of this study, he argues that 'news professionalism is an efficient and effective means for controlling professional behaviour of journalists' (Soloski, 1989, p. 224). For him, professional behaviour of journalists should manifest an efficient understanding of complex needs of their respective news organisations.

Hallin (1996) also discusses issues related to professionalism and journalism in American context and contends that the notion of professionalism is a contested matter in case of journalism. On the one hand, the ideal of professionalism is deeply rooted in the culture of journalism: every American journalist aspires to be highly professional and desires to serve the public through journalism; on the other, commercial imperatives create situations in which they become unable to serve the public independently; there has always been a tension between owners' prerogatives and journalistic independence. These two concepts - efficient understanding of respective news organisations and tension between owners' prerogative and journalistic independence-have been used to advance the argument here for understanding professionalism in freelance journalism. 


\section{Theoretical context}

Mainly two lines of argument are advanced in the debate concerning journalism and profession: one focuses on whether or not journalism is a profession (Merrill 2000); the other examines how the notion of professionalism is deployed in the practice of journalism (Hallin, 1996; Soloski 1989). However, there is another viewpoint which asserts the debate over whether or not journalism is a profession is unnecessary, because 'it is important to determine what it means for an occupation to claim it as a profession' instead of arguing whether or not it is a profession (Hughes, 1958, p. 45, quoted in Soloski, 1989, p. 207). This is why Soloski instead examines the relationship between journalists and their organisations to comprehend the issues in journalistic practices and the way the notion of professionalism affects journalists.

From sociological viewpoint, Larson (1977) writes of three dimensions of profession - cognitive, normative and evaluative. Cognitive dimension of professionalism focuses on the body of knowledge, training and techniques required for professional practice. Normative dimension highlights the issue of control and norms (for example, objectivity and commitment to public service in case of journalism). The evaluative dimension examines the notion of autonomy and prestige in occupations. Autonomy can be explained from the viewpoint of public interest, that is, who they are serving and how they perceive their accountabilities in their everyday practice. Similar to Larson's three dimensions, Soloski (1989) considers that professionalism in journalism is constructed from news professionalism, professional norms and professional 'ladder'. The understanding of news professionalism is developed from journalism education and on-the-job training which in most cases is provided by external educational institutions. Journalism is one of the contemporary professions operating 'within profit making business organisations' (Soloski, 1989, p. 209) in which their work depend on the 'choice' of the media employers rather than the independent judgment of the practitioners. Soloski further finds that the notion of objectivity plays a significant role in the way journalists deal with various needs or demands of the news organisations, readers and other journalists. In this process, journalists reinforce the ideology of their profession through underpinning the values and norms of the existing power structure in society (Soloski, 1989, p. 215; see also Tuchman, 1978; Gans, 1979). However, they do not consciously intend to produce news to support the existing dominant 'political economic system', but their 
professional norms legitimise the existing order by making it appear to be a naturally occurring state of affairs' (Soloski, 1989, p. 225). The sustainable practice of professional norms evaluated through professional rewards and recognition (professional ladder) enable them to exercise their 'individual freedom', provided they have an understanding of the requirements of their organisations. Although news policies do limit journalists' professional behaviours, journalists do not necessarily see the policies as constraining their work (Soloski, 1989 , p. 226) since 'professional norms and news policies' are rules of the game which journalists learn to 'play by' (Soloski, 1989, p. 218). News organisations operate in a highly unpredictable environment, thus a more flexible type of control is required in dealing with different situations making the nature of professionalism always contested and dependent on individual news organisation and its news policy (Soloski, 1989, p. 214). This argument of variability of professionalism is analogous to Bourdieu's notion of 'rules of games' in his theory of field (Thompson, 1991). Bourdieu contends that individuals ('agents') in a field engage in 'games' or a process of maintaining or altering their position (preserving or acquiring certain capitals) according to mutually agreed upon rules. These rules are not static and constant, rather dynamic and fluid; they alter all the time because of various circumstances. Such fluidity of rules of games is highly visible in case of journalism because most of the situations in this occupation are contingent, not predetermined (Benson, 2005).

Friedson (1994) and Reese (2001) support Soloski's (1989) argument that a sociological concept of professionalism, which is applicable to occupations such as medicine and the law, is not adequate in understanding 'newer dependent' professions such as journalism. Friedson (1994, p. 27) further asserts the notion of profession cannot be formulated in a single definition because of the complex character of different practices and perspectives. Reese (2001) uses this argument to assert that in case of journalism 'the meaning of professionalism needs to be understood in relation to its specific cultural context'.

The importance of specific occupational cultural context becomes evident when we examine the example of freelance journalists. According to conventional sociological interpretation, professionals are supposedly independent in providing service to the public. Freelance journalists in many cases are unable to defend their 'professional' independence, as they work without any organisational attachment or support, which renders them vulnerable to 
the power of the media organisations (Das, 2005). This raises question about their claim of independence and being professional in practice, and requires us to consider the specific occupational culture in explaining their notion of professionalism. So the important question here is how freelance journalists perceive their position in regard to the notion of professional independence in journalism, and how in actual practice this notion is played out. In the interviews with freelance journalists for the current research, emphasis has been given on how freelance journalists define professional independence, accountability and control over their work, required skills and expertise to ensure sustainability and the implied meaning of public interest they serve. By examining these issues, this study endeavours to find out how well-founded their claim of professionalism and independence is.

\section{Methodology}

In analysing the notions of professionalism among freelance journalists, it has been considered that knowledge about a dynamic social reality cannot be completely captured by quantifying certain variables (Denzin \& Lincoln, 2000). So, qualitative interviews of Sydney-based freelance journalists have been considered as the best option available for this inquiry. Moreover, following a number of local and global surveys (quantitative investigations) on work conditions of freelance journalists, adopting qualitative method seems necessary to substantiate the quantitative data in analysing freelance situation. A total of 18 freelance journalists, who contribute to the national and metropolitan dailies published from Sydney, were interviewed anonymously to discern how they perceive professionalism in their journalism practice. Of the interviewees, fourteen were female and the remaining four were male; twelve of them obtained tertiary education while six did not have formal university education but attended different profession-related refreshers trainings. One of the important criteria for selecting interviewees was to find out those journalists who were mainly earning their living from freelance journalism. This resulted in the selection of experienced and active freelancers, a sample which does not provide a proportionately representative selection of the total freelance population in Sydney. Reputed and high profile freelance contributors were also excluded in this study on the assumption that they did not necessarily earn most of their livelihood from freelance work. The semi-structured interviews were based on pre-tested questionnaire and lasted between 60 and 90 minutes. Anonymity was granted to the 
interviewees because it was found in questionnaire pre-testing that prospective respondents were concerned about possible risks on future work of revealing their identity. In a number of cases, follow-up short interviews were conducted to further clarify the statements made by some interviewees. The interviews commenced in July 2003, and continued till March 2005. However, the first round of interviews was completed by June 2004.

In order to obtain an overview of the existing situation in practical freelance work in Sydney print media market, this researcher came into contact with the Media, Entertainment and Arts Alliance (MEAA), the federal union body of the Australian journalists and performers, and attended its sixth annual convention for freelance journalists, which was held in Sydney in April 2003. The deliberations of this convention assisted greatly in developing an insight into the everyday life of the freelancers. Armed with this knowledge, a careful process was followed to select suitable interviewees. The aim was to gain a good in-depth insight into this particular occupation; so the journalists with significant experiences in freelancing had been selected. The range of experience of the final sample of 18 interviewees varies from three years to 35 years. They contribute to metropolitan broadsheets, local publications as well as to news media abroad. All the respondents had been freelancing at the time of interviews for one to three news organisations, including contributing to the supplements of two Sydney broadsheets (careers, architecture, travel, surfing, finance, fashion, entertainment, technology, health, technology, community etc.) and magazines. The freelancers have specialisations in certain areas but are able to cover a wide range of topics according to the need of the publications. They generally do not work on hard news stories, and only one interviewee claimed he did some investigative stories. Although they were regularly contributing to the same organisations, they did not hold any permanent positions with those organisations; rather they supplied editorial copies on contract basis. However, four of the interviewees worked as employed journalists before commencing freelancing.

In addition to freelance journalists, three commissioning editors were also interviewed for the research, but they were not asked about the issues relevant to professionalism and freelance journalism.

\section{The findings}

Attitude to professionalism

All the freelance journalists interviewed have considered themselves as

148 PACIFIC JOURNALISM REVIEW 13 (1) 2007 
professionals, and majority also believed they had to be more professional compared to their employed counterparts since they operated in the industry independently and without any support from big media organisations. One of them, who is now contributing to newspaper supplements, magazines and a number of international outlets, perceived the notion of professionalism as even more important for freelancers than for employed journalists and said,

I am a freelance journalist; that does not mean I am not going to be a professional. I see (freelancing as) an extension of what I have done in the past in my career. You have to be professional ... (if) you don't have credibility, people can even tell over phone, they are not going to trust you.

Another interviewee, who came to freelancing from a wire service, also claimed to be a professional but placed a different emphasis on what the notion implied.

I consider myself as a professional. I do my work to as high standard as I can, act in a professional way to my employers, if they ask for something. I deliver it on time and if I have any trouble, let them know as early as possible.

Freelance journalists saw the notion of professionalism as an integral part of journalistic practice and should be demonstrated in the journalists' responsibilities towards the public. When asked about whether they believed in any role as journalists to the service of the public, 15 interviewees out of 18 believed they had a responsibility towards 'public interest'. Two respondents observed the notion of public interest or public service was often related to the situation and type of story they were commissioned to undertake. Another interviewee, who strongly supported the notion of public service, perceived the role of public service for freelance journalists the following way:

It depends on the story. Sometimes I am purely an entertainer, sometimes I inform the people, but sometimes I can do both at the same time, but as naïve and altruistic as it sounds, I pretty much write to make a difference to the people, to give readers some information they hadn't had before, 
a new way of looking at the situation ... if that wasn't important to me, I would've been in advertising, I have been making 250,000 dollars a year writing slogans ... I mean, almost a noble aspect of journalism is something I hang on to quite tightly.

This strong feeling of responsibility towards the public is important to note here, because this strong public service perspective is equally available among employed journalists. Another freelance journalist, who worked as a staff writer in a wire service, even said she was prepared to turn down a lucrative offer of non-journalistic work to make sure her integrity as a journalist was not jeopardised. She believed that every freelancer needed to maintain some sort of policy on what types of non-journalistic writing commissions s/he would accept. As an example, the respondent said she was offered handsome payment to write a report on New South Wales health policy which involved accessing confidential documents. The documents contained 'really good story' for any journalist. She said,

As a journalist I would have been bound to write that story. But to my employer, I was to write a confidential report. Then I would have to censor myself as a journalist. So it would have been probably a horrible conflict of interest. In the end we both agreed, it's probably not a good thing to do so. I didn't do it. I am glad I didn't do it.

For these two freelance journalists, the notion of public service in professional practice is more important than any lucrative financial offers from other non-journalistic work. Not everyone espoused such strong notions of public service. Two out of the 18 respondents were not sure about their role in serving the public and placed more emphasis on accomplishing the tasks competently. One of them, who also worked as a corporate writer, said 'I want to do a good job and ensure that it's appropriate for the publication'. The other, however, associated her role as enabling audiences to 'think and question'. The only interviewee, who did not subscribe to the notion of public service in freelance work and strongly believed that journalism was a commercial product, said: 'Obviously I like to write about what people are interested in, but I don't think I am doing any good for the society by working on my own...' 
From the above excerpts, it seems there has been a wide support for strong public service model of journalism among freelance journalists in Sydney's print media, although for some, being professional simply means doing the job efficiently and skilfully. 'Commercial' value of the 'product' is also important to many freelancers, which indicates ambivalence towards high ideals of public service notion.

\title{
Professional norms
}

In journalism, objectivity has long been an issue of debate as it raises many complex questions, such as whether or not objectivity in journalism is possible or desirable (Lichtenberg, 1995, p. 35). The term 'objectivity' is usually associated with other notions such as balance, accuracy and truthfulness. On the question of whether they felt they were able to tell the truth in their stories, 13 freelancers said they did not face any problem in telling the truth. Five interviewees, however, observed it was hard to maintain professional integrity because of various pressures active on them: freelancers had no institutional affiliation which might assist them in sticking to the findings of their investigations. Others rejected any pressure from their organisations in writing stories, but said they had to have a very good understanding about what to write and what not to write. The story might be worth telling because they reveal some important truths to the readers, but they always needed to be aware of their limitations as freelance journalists. Three journalists found themselves in situations in which their stories impinged on the news organisations' commercial interests. One of them researched 'dodgy apartment buildings' in Sydney and said,

\begin{abstract}
...there are lots of concerns because we criticise major developers, who advertise in our paper. Occasionally [the stories] even go through the lawyer. The particular advertiser took three to four pages every single week, so millions of dollars a year. There are also political allegiances. You have to work to fit into a structure. You can't write what you want, the person you write for ... trick your idea and the editor trick your idea
\end{abstract}

Two other interviewees also talked about pressure to comply, 'to fit into a structure'. One freelance humour writer said: 'I haven't had any people telling me, forbidding me to write on certain areas or certain topics, again you kind of tailor your contents to your audience.' Four freelancers said that 
if they were not comfortable with a story idea, they would reject the commission. But when asked about continuity of subsequent commissioning if they refused to work on a given idea, they stated that they had to keep that factor in mind while refusing any commission. In such circumstance, they would need to be polite and 'diplomatic'. They perceived this rejection of commissions as one of the opportunities as an independent journalist to exercise some power in story selection. One freelancer said this capacity to decline a story gave him more independence than what he experienced as an employed journalist.

We can't always write what's really happening out there, sometimes
editors have angles for the stories, that's what you want to go for but
I used to get more pressure as a staff journalist than I ever got as a
freelancer. As a staff journalist, you should write the way the editor
wants; as a freelancer you have the ability to say no, I am busy, thank you
very much. As a staff member ... you do things you don't want to do.

This comment reflects a complex attitude towards professional norms and the way in which these are negotiated in freelance practice. No interviewee said s/he had actually had to self-censor in work although needed to keep in mind an 'understanding' of the news organisations' requirements. A majority of the interviewees conceded that generally they were less likely to write stories on touchy or sensitive topics which might warrant self-censorship. The freelancers who had experienced constraints/organisational pressure in their work further perceived that it was necessary to have a strong knowledge about how to 'fit into a structure' and maintain a good relationship with the editors to successfully operate in the freelance marketplace. Freelancers tend to define objectivity according to occupational needs in which the parameters of truth are defined by the news organisation and by the freelancer's position in the market. This reflects Soloski's (1989, pp. 213, 227-228) argument on professional norms that journalists perform their duties in a way that legitimises the interests of the media organisations. In describing their experiences, freelancers generally had not expressed their frustrations about the organisations they work for or mentioned any pressure from the editors. Yet, the requirement of 'fit into structure' reflects that being a journalist it is important to have a good understanding about the news 
organisations and its audiences. It also characterises the notions of 'field' and 'news professionalism' put forward by Bourdieu and Soloski respectively. Bourdieu argues that the acceptance of norms by 'agents' in a field is part of the 'rules of the game' which the players must abide by in order to engaged in the game (Thompson, 1991). Soloski also talks about the same rules of the game played by the journalists working in a news organisation: "professional norms and news policies are rules everyone has learned to play by" (1989, p. 218).

Skill of the journalists

All freelance journalists interviewed for this study believed that freelancers needed to be highly skilled to sustain themselves in a competitive market. In addition to some essential journalistic skills, the freelancer also put emphasis on networking and marketing skills. One interviewee asserted that required skills for freelance journalists were difficult to define, but they might involve the following:

...you need to have an intimate knowledge of the subject matter, you got to have required journalistic and editorial skills to transform that knowledge into marketable commodity, [and you have to have the] ability to get out and kick down the door and sell the stories

He further asserted that the journalists needed to be determined in selling the ideas or stories, because many times '... I got the assignment not necessarily [because] I am the best person for the job, [but] because I have been most vigorous' in pursuing the commission.

From the above evidences, it is evident that freelance journalists see themselves as possessing both high-end journalistic skills and strong marketing abilities reflecting the complex situation in which freelance journalists are engaged in continuous struggle against fellow practitioners. The journalists believed that they must continually prove their worth in order to get commissioned and for editors to choose their story ideas. As one freelancer puts it, 'you have to redefine yourself every time' to sustain yourself in the market. While a basic requirement is strong knowledge of their occupational practice, it is their marketing ability that matters most. Without this particular ability of salesmanship, their sustainability as freelancers would be threatened. 


\section{Attitude to journalism education}

Education is one of the important attributes associated with professionalism. Of the 18 interviewees, eleven journalists had undertaken undergraduate or postgraduate university studies in journalism or communication, while seven did not. Of the 11 who studied relevant degrees in the universities, four did not consider such studies as particularly helpful in their profession life, while the remaining seven thought education had significantly enhanced their position in the profession. On the other hand, two interviewees out of the seven who did not have formal education viewed such education as important; the remaining five thought such education was not very important. Altogether, half of the respondents (nine out of 18) considered journalism education as necessary and relevant for their work; the other half viewed it as less important in work.

One interviewee, who obtained postgraduate degree and came to freelancing, thought that studies in journalism taught her structure of news and feature writing and editing, ideas about media industry and provided some valuable connections. Another interviewee, who had no formal education in journalism, also felt that such education was necessary because it might be of help in competition: "it [freelancing] is an extremely difficult area of journalism, there are some hidden pitfalls, there are some rules and etiquettes, there are ways of dealing with editors ... [education] might make the path a little bit smoother."

One respondent, who preferred to be identified as a writer rather than a freelancer, considered that entry to journalism was getting tougher nowadays, and aspirants needed to stand out in the crowd. For this reason, formal institutional education in journalism sometimes helped enhance their positions in the market, but only just: 'When you submit your CV, it automatically puts you to the next level, next category, it opens door for you.' Although this interviewee had formal institutional qualifications in journalism, he did not consider such education as hugely essential in building a freelance career. However, he was not suggesting that the formal degrees were completely ineffective.

I did a communication degree at Macquarie University and I did a journalism diploma at ... a private college in Sydney. I think my particular degree in communication was a bit theoretical, it did not practically apply to my day-to-day journalism and I almost knew that 
while I was doing it (the degree), which is why instead of going for post-grad I did a practical hands-on diploma in journalism

Another journalist, who recently came to freelancing after leaving her staff job, thought on the other hand that formal education in journalism and on-the-job training in newsroom were not only necessary, rather very much essential. She suggested that

\begin{abstract}
...it's good to have included a course on freelancing in communication and journalism courses, because there are a lot of things specific to freelancing you need to know, but also I think freelancers are particularly mindful of ethical issues. One of the problems with freelancer who [have] gone to freelancing without having an experience in newsroom is that they don't [sic] aware of the code of ethics, which is really important
\end{abstract}

Similar to this, another freelancer, who had been contributed to career supplement section in a metropolitan broadsheet, said it was very important to obtain formal education to be able to properly deal with difficult (ethical) situations, in which the freelancers needed to be aware of their limits. The freelancers needed to know what to write and what not to write; otherwise their subsequent commissioning might be jeopardised as a result of unnecessary promotion of others' causes in their writings. The relationship between formal education in journalism and better ability to deal with difficult situation, however, is open to further analysis and interpretation.

On the contrary, some respondents suggested that formal education in journalism was less important. One interviewee, who had no formal education in journalism, considered that journalism was a craft, and there was no significant knowledge to be taught; for him, journalism was 'more intuitional than institutional'. In support of this view, another freelancer said journalism is hard to teach because '...the journalists are instinctive.' He said:

... the interest in journalism and literature is worthwhile, but I don't know if you need formal qualification, there are plenty of examples where people have very few formal qualifications... but become very 
good journalists. I think it's personality, ambition, hard work [and] love of language

The interviews further demonstrated that freelance journalists' attitude towards journalism education was influenced by the ongoing debate over the issue in which some critics, such as Schultz (1994, p. 213) and O'Donnell (1999, p. 133), argued that formal education in journalism needed not to have any direct contribution towards success in work, while others (Guerke \& Hirst, 1996) claimed such education should enhance the capacity of critical thinking which was essential in constructing news stories.

\section{Flexibility}

Some respondents said they came to freelance journalism mainly due to flexibility and variety of options it offered to them. This flexibility is an important aspect of freelance practice. Since freelancing is contract-based work, freelance journalists are theoretically more independent compared to employed journalists. But relentless uncertainty over getting commissioned creates a difficult situation for the freelancers. The responses in this study indicated that majority freelancers thought they were completely independent of 'office politics' which facilitated them to work on their own pace. They did not have to be concerned about various formal involvements and procedures of the workplace. One interviewee observed that freelancing offered him freedom of choice for assignments, which was lacking in his employed work. According to another respondent, freelancing also offered flexibility in working hour and lifestyle choice. She said,

Freelance journalism has always been appealing to me because of the independence it offers you, from a editorial point of view and just from a lifestyle point of view that you are not tied down to nine to five, you can come and go, you got your choice of subject matters and things you can cover, just basically freedom and independence.

While most freelance journalists longed for a permanent job in the media, there were others who were not willing to have one for the sake of flexibility and independence. According to three respondents, flexibility to work at their own pace turned out to be enormously helpful for them, particularly when they had additional responsibilities such as raising a family. 
In contrast to this view, five respondents have rejected outright the notion of independence in freelancing. One strongly opposed the incorporation of independence in freelance practice, and said:

I depend on my client, to make a living ... I am [also] dependent on demographics ... I need to tailor my material so that the magazines keep on commissioning me, so in that way I am not independent but I ... can come up with stories on my own. I can exercise the independence of mind quite fully, but as long as I remember of that parameter who I am writing stories for, who is reading the magazine or newspaper basically, I can be as free as I want to...

Another interviewee, who has been worked in the industry for more than three decades, echoed this view in almost an ironic tone:

I don't think they [freelance journalists] are at all independent ... there are freedom for freelancers, seven days a week 24 hours a day ... always thinking about ideas, that phone call, how I got my check, where is my invoice and always re-inventing the wheels, you finished one story, and you think, now I am nothing. You are only good as your last story. So it's quite a kind of anxiety ridden way to make a living. Your time and equipment, your tools, overhead and your bills (are) all yours. I don't think there is any freedom, freedom of coming home, because I am at home already

The responses showed that there was very little room for independence because the freelancers' individualised practice without any institutional affiliation made them powerless in the periphery of media work. While some respondents considered the issue of independence from lifestyle or flexibility perspective which enabled them to exercise some degree of personal freedom, majority expressed discontent on the notion of independence particularly due to continuous financial insecurity.

\section{Conclusion}

Overall, an intricate position emerges in the way freelance journalists use the notions of professionalism and independence to legitimise their decision to act as journalists. Whereas employed journalists could mobilise, as 
Hallin (1996) observed, notions of independence and professionalism against the commercial imperatives of employer organisations, freelancers can also make claims to independence and take a stand against interference; but for the most part the only practical control they have is to walk away from the commission. Freelance journalists know that to maintain a place in the field, they must keep getting commissioned. While their notion of public service may sustain them, most of them in practice know that they must negotiate the informal requirements of media organisations; and the most important imperative is to play the game by the rules mainly set by the news organisations (Soloski, 1989).

More broadly from the point of view of Bourdieu's field analysis, one can see that notions associated with professionalism do play important symbolic roles in journalists' sustaining of position within the field. However, these notions are adapted to 'rules of game' set by others. Evidences suggest that journalists are reluctant to see that their own professionalism is compromised in story selection or research. Despite the reluctance of the journalists to compromise their professionalism, they are in many instances powerless and have to comply with the requirements of the news organisations.

In conclusion, it can be asserted that freelance journalists seem to evoke the idea of professionalism despite constraints affecting their independence; reality of their work made freelance journalists accept the imperatives of the rules of game set by news managers, which is a compromise in their independence. So, despite strong public service ethos, the claim of freelance journalists of being professional is weak.

\section{References}

Baines, S. (1999). Servicing the media: Freelancing, teleworking and 'enterprising' careers. New Technology, Work and Employment, 14 (1): pp.18-30.

Baines, S. (2002). New technologies and old ways of working in the home of the self-employed teleworker. New Technology, Work and Employment, 17 (2): pp. 89-101.

Baumann, A. (2002). Informal labour market governance: the case of the British and German media production industries. Work, Employment and Society. 16 (1): pp. 27-46.

Benson, R. \& Neveu, E. (2005), Bourdieu and the journalistic field. Cambridge: Polity Press.

Bourdieu, P. (1991). Language and symbolic power. J. B. Thompson (Ed.), trans. G. Raymond, G. \& Adamson, M. Cambridge: Polity Press/Basil Blackwell. 
Das, J. (2005). Constraints on freelance journalists in Australian print media. Unpublished Master of Arts thesis. Sydney: University of Technology, Sydney.

Denzin, N. K. \& Lincoln, Y. S. (2000). The handbook of qualitative research. Thousand Oaks, CA.: SAGE.

Dombkins, M. (1993). The impact of technology and environmental factors on newspaper organisational design. Australian Journalism Review, 15 (1): pp. 29-51.

Dunn, A. (2003). From quasi to fully: on journalism as a profession. Australian Journalism Review, 26 (2): pp. 21-30.

Franklin, B. (1997). Newszak \& Newsmedia. London: Arnold.

Friedson, E. (1994). Professionalism reborn: theory, prophecy and policy. Cambridge, UK/Chicago: Polity Press/University of Chicago Press.

Freidson, E. (2001). Professionalism: the third logic. Chicago: University of Chicago Press.

Forde, E. (2003). Journalists with a difference: producing music journalism. In Cottle, S. (Ed), Media Organisations and Production. London, Thousand Oaks, New Delhi: Sage.

Gans, H. J. (1979). Deciding what's news: a study of CBS Evening News, NBC Nightly News, Newsweek, and Time. New York: Pantheon Books.

Gottschall, K. (1999). Freelance work in journalism, changing of employment patterns between self-employment and wage-earning work. Trans. Emma O'Brian, Kolner Zeitschrift fur Soziologie und Sozialpsychologie. 51(4):pp. 635-654.

Gottschall, K. (2002). New forms of employment in Germany: labor market regulation and its gendered implications. Occasional paper series No. 8. College of Urban Labor and Metropolitan Affairs. Wayne State University: Detroit, Mi. (Retrieved 18 August 2004): www.culma.wayne.edu

Guerke, L.; and Hirst, M. (1996). Across the genres: how journalism is changing in the 1990s. Australian Journalism Review, 18(1): pp. 117-132.

Hallin, D. C. (1996). Commercialism and professionalism in the American news media. In Gurevitch, M. and Curran, J. (Eds.), Mass media and society (pp. 243264). London/New York/ Sydney/Auckland: Arnold.

Hughes, E.C. (1958). Men and their work. Glencoe, IL.: Free Press.

International Federation of Journalists (IFJ). (1999). Freelance futures: world survey of the social and economic status of freelance journalists. Brussels: IFJ.

Larson, M. S. (1977). The rise of professionalism a sociological analysis. Berkley/Los Angeles/London: University of California.

Litchenberg, J. (1995). In defence of objectivity revisited. In Gurevitch, M. and Curran, J. (Eds.), Mass media and society. London/New York/Sydney/Auckland: Arnold.

Meadows, M. (2001). A return to practice: reclaiming journalism as public conversation. In Tapsall, S. and Varley, C. (Eds.) Journalism theory in practice (pp. 40-54). Melbourne: Oxford University Press.

Meehan, K. (2001). It's hard life for freelancers. Australian Journalism Review, 23 (1): pp. 99-101. 
Merrill, J. C. (1996). Journalism is not a profession. In Dennis, E. E. and Merrill, J. C. Media debates: Issues in mass communication (pp. 209-211). New York: Longman.

O'Donnell, P. (1999). The other 66 per cent? Rethinking the labour market for journalism graduates. Australian Journalism Review, 21(1): pp. 123-142.

Platman, K. (2003). The self-designed career in later life: a study of older portfolio workers in the United Kingdom. Aging \& Society, 23 May: pp. 281-302.

Rees, S. D. (2001). Understanding the global journalist: a hierarchy-of-influence approach. Journalism Studies, 2(2): pp. 173-187.

Schultz, J. (Ed.) (1994). Not just another business journalists citizens and the media. Leichhardt, NSW: Pluto Press.

Singer, J.B. (2003). Who are these guys? The online challenge to the notion of journalistic professionalism. Journalism theory, practice and criticism, 4(2): pp. 139-163.

Soloski, J. (1989). News reporting and professionalism: some constraints on the reporting of the news. Media, Culture and Society, 11: pp. 207-228.

Tuchman, G. (1978). Making news: a study in the social construction of news. New York: Free Press.

Thompson, J. B. (1991). Introduction. In Bourdieu, P. Language and symbolic power. Trans. Raymond G. and Adamson. M. Cambridge: Polity Press/Basil Blackwell.

Tunstall, J. (1996). Newspaper power: the new national press in Britain. Oxford: Oxford University Press.

Jahnnabi Das is currently teaching part-time a media subject at the University of Technology, Sydney, after recently completing her MA research degree in journalism from the same university. She has extensive professional experience in print journalism.

Jahnnabi.Das@uts.edu.au 